\title{
Landslide risk management in Australia 2013 - status of resources available to practitioners
}

\author{
A. Leventhal GHD Geotechnics, Australia
}

A. Miner AS Miner Geotechnical, Australia

B. Walker JK Geotechnics, Australia

\begin{abstract}
Through its national committee, the Australian Geomechanics Society (AGS) has long recognised the contribution of Landslide Risk Management (LRM) to the wellbeing of the Australian community. As part of a commitment since 1985, the Society recently undertook two initiatives: the 2011 LRM 'Risky Roadshow' seminar series conducted throughout the nation; and in 2012 the development of an interactive 'Education Empowerment' website specifically directed towards LRM.
\end{abstract}

The principle objective of these initiatives was to communicate and educate, and thereby empower, landslide practitioners and regulators with knowledge and tools required to implement best practice LRM, as well as to provide information to the general Australian populace regarding landslide risk. These educational resources and tools are based upon the internationally recognised LRM guidelines and commentaries published by AGS in 2000 and 2007. It was appropriate to build upon the guideline outcomes through these recent initiatives to benefit the Australian community.

This paper provides background to the current status of LRM throughout the nation and provides advice on the package of resources available to assist practitioners in conducting landslide risk assessments.

\section{Introduction}

The Australian Geomechanics Society (AGS) has developed technical papers and guidelines for the management of landslide risk associated with hillside development since 1985. The most recent activities have been: a nationwide 'LRM Roadshow' in 2011; which was accompanied by the 'case histories' edition of Australian Geomechanics; and the development of an interactive website for empowerment by practitioners, regulators and the general public in landslide risk management matters in 2011 and 2012.

\section{$2 \quad$ How did we get to where we are in 2013?}

An abridged history of Landslide Risk Management (LRM) is presented in Table 1, covering the period from 1985 to the present - see also Leventhal et al. (2012). Several significant milestone publications have been produced over the last 28 years during which LRM advanced within Australia (Figure 1), as well as across the globe. 

Table 1 Abridged history of the development of LRM within Australia. Briefly, the steps along the way in the development of a meaningful LRM framework for the nation have been as follows

\begin{tabular}{cl}
\hline Year & \multicolumn{1}{c}{ Formative Event } \\
\hline 1985 & $\begin{array}{l}\text { (Walker et al., 1985), as an AGS sub-committee, developed a technical paper on hillside construction in } \\
\text { Sydney (over a matter of several months). This has subsequently been recognised as likely to be the first } \\
\text { international use of the term 'risk' in association with hillside development. }\end{array}$ \\
1993 & $\begin{array}{l}\text { Sub-committee re-convened to review and update the } 1985 \text { paper, and did so as per the conventional AGS } \\
\text { approach at the time as volunteers in recognition of shortfalls in the earlier paper inter alia as a } \\
\text { consequence of international recognition of risk assessment and risk management. }\end{array}$
\end{tabular}

1997 Thredbo Landslide occurred on 30 July with 18 fatalities and brought to the attention of the Australian public the issues and challenges associated with landslides.

2000 AGS (2000) published (following a seven year gestation from 1993).

2000 Hardcopy of AGS (2000) distributed to each LGA and selected State, Territory and Commonwealth government departments throughout Australia.

2000 Coroner Hand determined his inquiry into the Thredbo landslide. Amongst many recommendations, Coroner Hand strongly recommended the adoption of AGS (2000) by those involved in regulation of hillside construction.

2002 Nationwide 'Risky Roadshow' to promulgate AGS (2000) to practitioners and regulators.

2004 Non-compulsory LRM Guideline developed as a reference document to the Building Code of Australia (BCA).

2005 International Conference on LRM held in Vancouver (Leventhal and Walker, 2005a), followed by distribution to the membership of AGS of modified conference paper (Leventhal and Walker, 2005b) explaining the status of LRM framework at that time and the strategies adopted for implementation of the principles of AGS (2000) into legislative framework.

2005 Landslide Taskforce convened, leading to development of AGS (2007) suite.

2005- Development of proposed NPER (LRM) guideline with details provided to membership of AGS, published in

2006 Australian Geomechanics (AGS, 2006) and forwarded by AGS National Committee to the National Engineering Registration Board (NERB) for implementation in government areas where practitioners are required by legislation to demonstrate competence - unfortunately, still waiting for this outcome to be realised.

2006 International workshop on LRM held in Barcelona (by invitation) where Australia represented and contributed to workshop through its leadership in LRM issues. Led to international versions of AGS (2007a and b) published by JTC-1 in 2008.

2007 AGS (2007) published as a suite of guidelines that provide an update of AGS (2000) in recognition of shortcoming therein and improvements in international risk management.

2007 CDROM copy of the suite of AGS (2007) distributed to each LGA and selected state and commonwealth government departments throughout Australia.

2007 Landslide susceptibility issues addressed by revision of Pittwater LGA landslide policy within its building development protocols.

2007 Geoscience Australia published 'Natural Hazards in Australia', with Chapter 8 dealing with landslide risk management with major contribution from AGS.

2007 Hong Kong Landslide Disaster Management workshop on landslide disaster management where Australia represented and contributed to workshop through its leadership in LRM issues.

2008 International guideline and commentary for LRM in land use planning published in international technical press (Fell et al., 2008a and 2008b). These were both significantly based upon AGS (2007a and 2007b). 


\begin{tabular}{|c|c|}
\hline Year & Formative Event \\
\hline $\begin{array}{c}2010- \\
2011\end{array}$ & $\begin{array}{l}\text { Contribution to, and ongoing discussions with, Tasmanian Government in regard to provisions in state } \\
\text { regional planning schemes for LRM. }\end{array}$ \\
\hline 2011 & $\begin{array}{l}\text { Risky Roadshow } 2011 \text { to promulgate AGS (2007) to both regulators and practitioners presented by AGS } \\
\text { nationwide. Success of the Risky Roadshow } 2011 \text { across the nation demonstrated through } 479 \\
\text { registrations and request to deliver seminar in Townsville. }\end{array}$ \\
\hline $\begin{array}{c}2011- \\
2012\end{array}$ & $\begin{array}{l}\text { Ongoing discussions with Queensland Department of Community Safety in regard to their updating of } \\
\text { State Planning Policy } 1 / 03 \text {, 'mitigating the adverse impacts of flood, bushfire and landslide', whilst } \\
\text { particularly noting that Queensland is the only state government that has legislation that addresses LRM } \\
\text { issues within its natural hazard management process. }\end{array}$ \\
\hline $\begin{array}{c}2011- \\
2012\end{array}$ & $\begin{array}{l}\text { Development of LRM EE website (launched 2012) to empower regulators, practitioners and the general } \\
\text { public. }\end{array}$ \\
\hline
\end{tabular}

The suite of papers AGS (2007a to 2007e), known collectively as AGS (2007), is one of those publications. Therein, the methodology of LRM was presented. As depicted in Figure 2, the process builds sequentially, as it logically steps through:

- Risk analysis.

- Risk estimation.

- Risk assessment.

- Risk management.

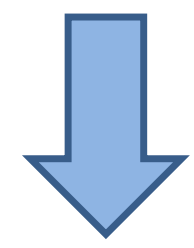

The specific details of the LRM process are not repeated herein since they are provided within both AGS (2000) and its successor AGS (2007). In addition, presentations are contained within the LRM EE website, to which the reader should refer for guidance.

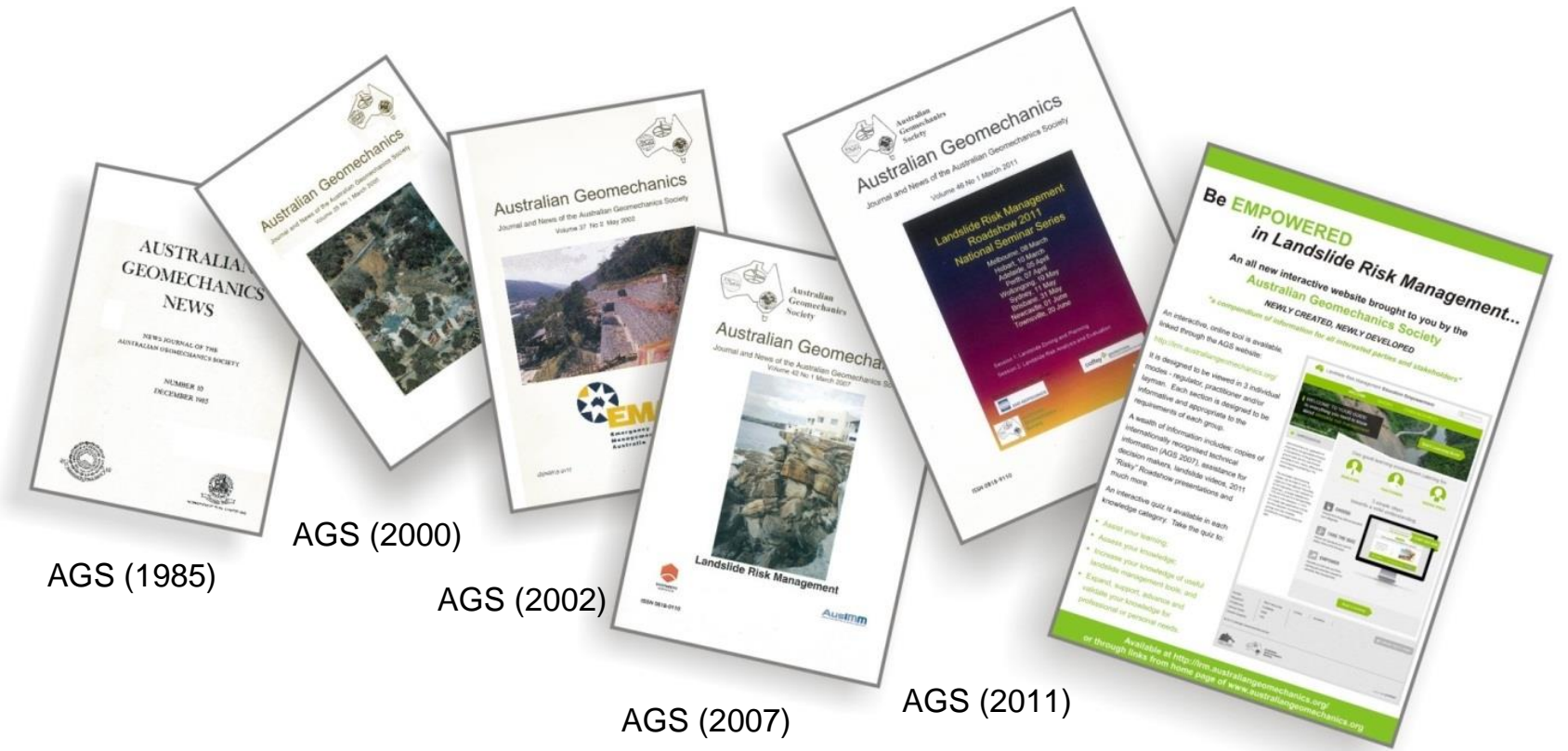

AGS LRM EE website (2012)

Figure 1 Significant milestones in technical contributions to LRM in Australia with 'headland' publications provided by the AGS. AGS (2000) and AGS (2007) are downloadable from both the AGS website and the LRM Education Empowerment (LRM EE) website (which is linked from the AGS website) 
Figure 2 illustrates that the framework is linked from one step to the next, and develops progressively through the steps.

The technical tools that are at hand for regulators, practitioners, and the general public, to assist in performing, managing and understanding the process include:

1. AGS (2007a and 2007b) - landslide zoning and commentary.

2. AGS (2007c and $2007 d)$ - practice note and commentary.

3. AGS (2007e) - Australian GeoGuides.

These tools can be accessed from both the AGS website and the LRM EE websites, and can be read at or downloaded from both.

Some of the contributory technical papers, guidelines and external processes supporting the LRM process that lead to the LRM framework are illustrated in Figure 3, where the interrelationship of the guidelines, regulator policies and technical papers is depicted diagrammatically.

An example of a particular risk matrix that is recommended by the AGS for qualitative Landslide Risk estimation of loss-of-property is provided in Figure 4. Risk estimation for loss-of-life should be conducted in a quantitative manner to permit assessment through comparison with international and national criteria (which are based upon quantitative measures such as acceptable or tolerable loss-of-life per annum) specific references and appropriate target risk levels are provided in Section 3.5 of AGS (2007c) and Section C8.2 of AGS (2007d) for discussion on, and background to, this as well as similar discussion in Section 4.2 of AGS (2000) on the logic of this recommendation. 
LANDSLIDE RISK ASSESSMENT \& MANAGEMENT

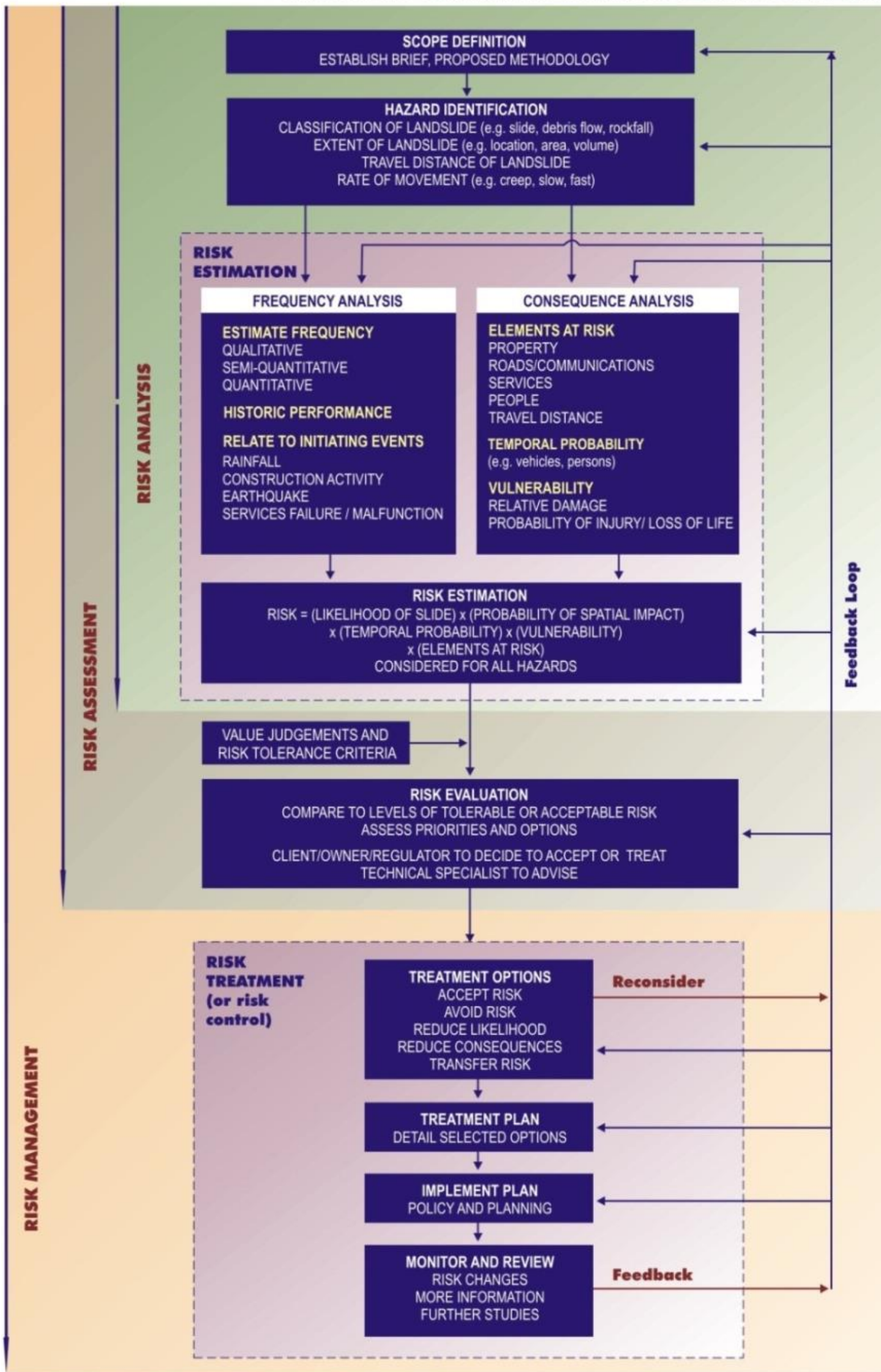

Figure 2 Depiction of the process of LRM 


\section{DEVELOPMENT OF SYSTEMATIC AND DEFENSIBLE LANDSLIDE RISK MANAGEMENT PROCESS}

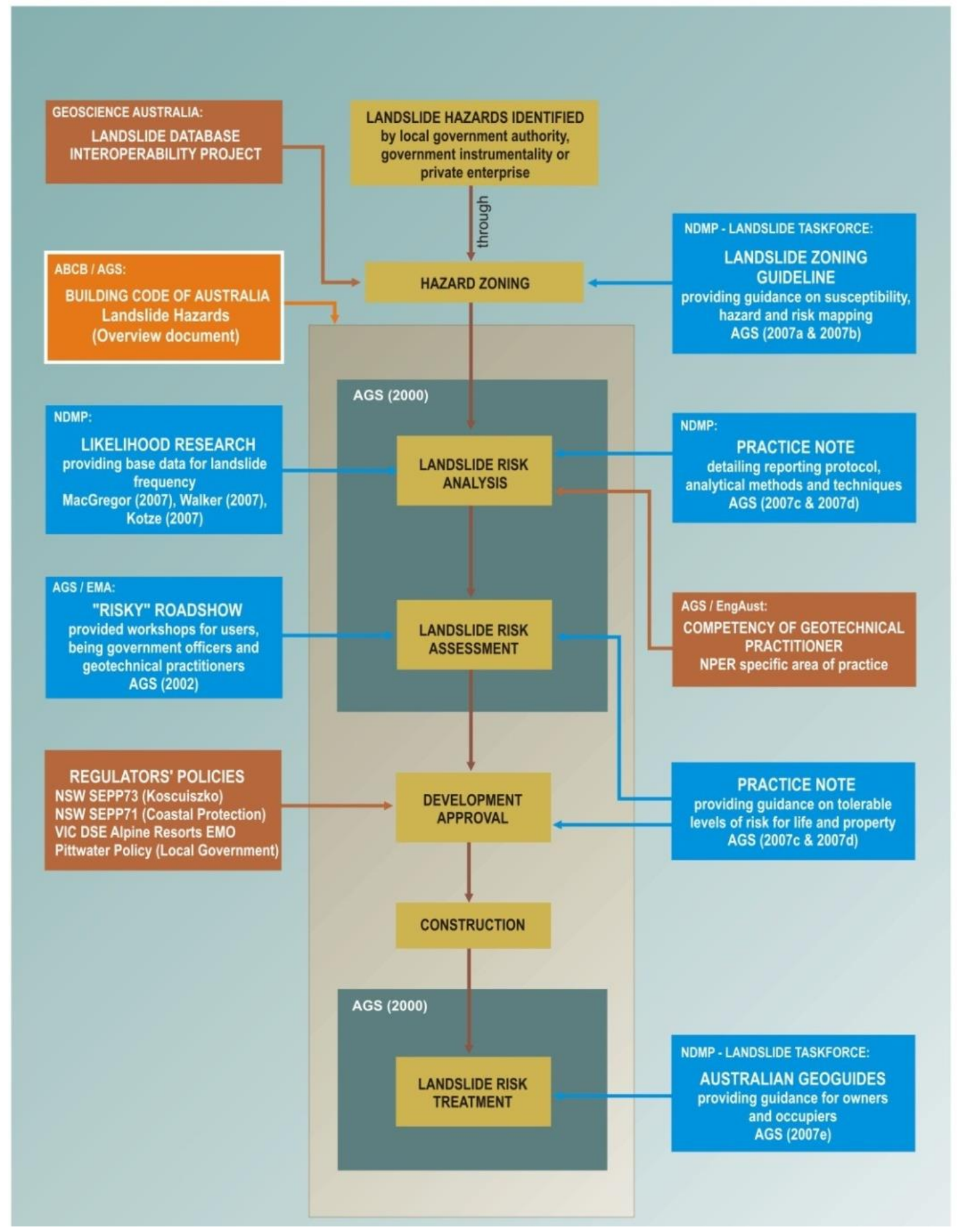

Figure 3 Depiction of the LRM framework illustrating both the framework and the interaction with activities and resources. (Reference should be made to Figure 2 for details of the central spine of the above framework) 
PRACTICE NOTE GUIDELINES FOR LANDSLIDE RISK MANAGEMENT 2007

APPENDIX C: LANDSLIDE RISK ASSESSMENT QUALITATIVE TERMINOLOGY FOR USE IN ASSESSING RISK TO PROPERTY

QUALITATIVE MEASURES OF LIKELIHOOD

\begin{tabular}{|c|c|c|c|c|c|c|}
\hline \multicolumn{2}{|c|}{ Approximate Annual Probability } & \multirow{2}{*}{\multicolumn{2}{|c|}{$\begin{array}{l}\text { Implied Indicative Landslide } \\
\text { Recurrence Interval }\end{array}$}} & \multirow[b]{3}{*}{ The event is expected to occur over the design life. } & \multirow{2}{*}{ Descriptor } & \multirow{2}{*}{ Level } \\
\hline $\begin{array}{c}\text { Indicative } \\
\text { Value }\end{array}$ & $\begin{array}{l}\text { Notional } \\
\text { Boundary }\end{array}$ & & & & & \\
\hline $10^{-1}$ & \multirow{2}{*}{$\begin{array}{l}5 \times 10^{-2} \\
5 \times 10^{-3}\end{array}$} & 10 years & $\begin{array}{l}20 \text { years } \\
200 \text { years }\end{array}$ & & ALMOST CERTAIN & A \\
\hline $10^{3}$ & & 1000 years & \multirow{3}{*}{$\begin{array}{l}2000 \text { years } \\
20,000 \text { years } \\
200,000 \text { years }\end{array}$} & The event could occur under adverse conditions over the design life. & POSSIBLE & c \\
\hline $10^{-4}$ & \multirow{2}{*}{$\begin{array}{l}5 \times 10^{-4} \\
5 \times 10^{-5} \\
5 \times 10^{-6}\end{array}$} & 10,000 years & & $\begin{array}{l}\text { The event might occur under very adverse circumstances over the } \\
\text { design life. }\end{array}$ & UNLIKELY & D \\
\hline $10^{-6}$ & & $1,000,000$ years & & The event is inconceivable or fanciful over the design life. & BARELY CREDIBLE & $\mathrm{F}$ \\
\hline
\end{tabular}

Note: (1) The table should be used from left to right; use Approximate Annual Probability or Description to assign Descriptor, not vice verse.

\section{QUALITATIVE MEASURES OF CONSEQUENCES TO PROPERTY}

\begin{tabular}{|c|c|c|c|c|}
\hline \multicolumn{2}{|c|}{ Approximate Cost of Damage } & \multirow[b]{2}{*}{ Description } & \multirow[b]{2}{*}{ Descriptor } & \multirow[b]{2}{*}{ Level } \\
\hline $\begin{array}{l}\text { Indicative } \\
\text { Value }\end{array}$ & $\begin{array}{c}\text { Notional } \\
\text { Boundary }\end{array}$ & & & \\
\hline $200 \%$ & \multirow{4}{*}{$\begin{array}{c}100 \% \\
40 \%\end{array}$} & $\begin{array}{l}\text { Structure(s) completely destroyed and/or large scale damge requiring major engineering works for } \\
\text { stabilisation. Could cause at least one adjacent property major consequence damage. }\end{array}$ & CATASTROPHIC & 1 \\
\hline $60 \%$ & & $\begin{array}{l}\text { Extensive damage to most of structure, and or extending beyond site boundaries requiring significant } \\
\text { stabilisation works. Could cause at least one adjacent property medium consequence damage. }\end{array}$ & MAJOR & 2 \\
\hline $20 \%$ & & $\begin{array}{l}\text { Moderate damage to some of structure, and or significant part of site requiring large stabilisation works. } \\
\text { Could cause at least one adjacent property minor consequence damage. }\end{array}$ & MEDIUM & 3 \\
\hline $5 \%$ & & Limited damage to part of structure, and/or part of site requiring some reinstatement stabilisation works. & MINOR & 4 \\
\hline
\end{tabular}

Notes: (2) The Approximate Cost of Damage is expressed as a percentage of market value, being the cost of the improved value of the unaffected property which

(3) The Approximate Cost is to be an estimate of the direct cost of the damage, such as the cost of reinstatement of the damaged portion of the property (land plus structures), stabilisation works required to render the site to tolerable risk level for the landslide which has $0 c c u r r e d$ and professional design fees, and consequential costs such as legal fees, temporary accommodation. It does not include additional stabilisation works to address other landslides which may affect the property.

(4) The table should be used from left to right; use Approximate Cost of Damage or Description to assign Descriptor, not vice versa

QUALITATIVE RISK ANALYSIS MATRLX - LEVEL OF RISK TO PROPERTY

\begin{tabular}{|c|c|c|c|c|c|c|c|}
\hline \multicolumn{3}{|c|}{ LIKELIHOOD } & \multicolumn{5}{|c|}{ CONSEQUENCES TO PROPERTY (With Indicative Approximate Cost of Damage) } \\
\hline & - ALMOST CERTAIN & $10^{-1}$ & $\mathrm{vH}$ & VH & vH & $\mathrm{H}$ & $M$ or $L(5)$ \\
\hline & - POSSIBLE & $10^{-3}$ & $\mathrm{VH}$ & $\mathrm{H}$ & M & M & $\mathrm{VL}$ \\
\hline & - UNLIKELY & $10^{-4}$ & $\mathrm{H}$ & M & $\mathrm{L}$ & $\mathrm{L}$ & $\mathrm{VL}$ \\
\hline
\end{tabular}

Notes: (5) For Cell A5, may be subdivided such that a consequence of less than $0.1 \%$ is Low Risk:

(6) When considering a risk assessment it must be clearly stated whether it is for existing conditions or with risk control measures which may not be implemented at the current time.

RISK LEVEL IMPLICATIONS

\begin{tabular}{|c|c|l|}
\hline \multicolumn{2}{|c|}{ Risk Level } & \multicolumn{1}{|c|}{ Example Implications (7) } \\
\hline VH & VERY HIGH RISK & $\begin{array}{l}\text { Unacceptable without treatment. Extensive detailed investigation and research, planning and implementation of treatment } \\
\text { options essential to reduce risk to Low; may be too expensive and not practical. Work likely to cost more than value of the } \\
\text { property. }\end{array}$ \\
\hline H & HIGH RISK & $\begin{array}{l}\text { Unacceptable without treatment. Detailed investigation, planning and implementation of treatment options required to reduce } \\
\text { risk to Low. Work would cost a substantial sum in relation to the value of the property. }\end{array}$ \\
\hline M & MODERATE RISK & $\begin{array}{l}\text { May be tolerated in certain circumstances (subject to regulator's approval) but requires investigation, planning and } \\
\text { implementation of treatment options to reduce the risk to Low. Treatment options to reduce to Low risk should be } \\
\text { implemented as soon as practicable. }\end{array}$ \\
\hline L & LOW RISK & $\begin{array}{l}\text { Usually acceptable to regulators. Where treatment has been required to reduce the risk to this level, ongoing maintenance is } \\
\text { required. }\end{array}$ \\
\hline Note: (7) & VERY LOW RISK & $\begin{array}{l}\text { Acceptable. Manage by normal slope maintenance procedures. } \\
\text { given as a general guide. }\end{array}$ \\
\hline
\end{tabular}

Figure 4 Risk estimation matrix recommended by AGS (2007) for qualitative LRM 
The authors specifically draw to the attention of the reader several key items to take-away from the work that has been done over the last three decades:

- A significant library of tools are available to the practitioner to conduct defensible LRM.

- Landslide risk assessments are complex and must be conducted by experienced personnel who are familiar with the methodology, both in the process and the limitations of the appraisal methods.

- An intimate understanding of the geological and geomorphologic processes relevant to a particular project being appraised is a fundamental requirement in the conduct of landslide risk analyses.

- Several methods are available to conduct landslide risk analyses ranging from qualitative to quantitative, though risk of loss-of-life should be conducted employing semi-quantitative or quantitative techniques so that assessment can be linked with internationally recognised criteria.

- A simple understanding of risk, in an engineering context, is that:

○ Risk = likelihood (of an event) $\times$ consequence (should that event occur).

- It is important that engineering reporting does not adopt colloquial usage of the word 'risk' which usually means likelihood in a qualitative sense since a hidden (high) consequence is included in the context of this usage. Engineering usage should include an appraisal of both likelihood and consequence for appropriate usage of the term 'risk'.

- The estimation of likelihood is usually the most difficult part of the risk estimation exercise. Guidance on methods to effect defensible estimates is provided in the Risky Roadshow 2011, for which reference can be made through the LRM EE website.

\section{$3 \quad$ LRM project status in Australia 2013}

The status of the most recent Landslide Risk Management activities is:

- The Risky Roadshow 2011 seminar series was successfully conducted nation-wide.

- A special edition of Australian Geomechanics (V46N2 2011) was issued to accompany the Risky Roadshow 2011, within which was presented case histories in the application and use of LRM from throughout the nation. Specific case histories were identified as relevant to each of the Roadshow venues.

- The interactive Education Empowerment website development task was launched just prior to the 11th Australia-New Zealand Geomechanics Conference 2012. It had funding assistance under the National Disaster Mitigation Program (NDMP). The outcomes of the Roadshow 2011 were provided gratis to the project by AGS.

\subsection{Nation-wide seminar series (Risky Roadshow, 2011)}

The seminar series (see Figure 5) was conducted in five tranches:

- (1) Melbourne - Tuesday, 8 March 2011.

- (1) Hobart - Thursday, 10 March 2011.

- (2) Adelaide - Tuesday, 5 April 2011.

- (2) Perth - Thursday, 7 April 2011.

- (3) Wollongong - Tuesday, 10 May 2001.

- (3) Sydney - Wednesday, 11 May 2011. 
- (4) Brisbane - Tuesday, 31 June 2011.

- (4) Newcastle - Wednesday, 1 June 2011.

- (5) Townsville - Monday, 20 June 2011.

The initial planning was for the first four tranches to be conducted but at the request of Townsville Council and local practitioners, an additional tranche at Townsville was conducted.

Each seminar occupied a full day - the morning session focused on regulator requirements and the afternoon session focused on practitioner needs.

The national Roadshow received strong response from practitioners, and variable response from regulators. There were 479 registrations throughout the nation. Feedback forms were distributed at each venue to gauge audience response and to improve the presentations. On average, about $43 \%$ of registrants provided feedback. It is fair to say that the feedback was very positive as to the quality and relevance of the presentations. The presentations benefited from this feedback and were progressively modified throughout the program. (The presentations can be viewed through the interactive LRM EE website - see below).

The seminars were presented face-to-face by Bruce Walker and Tony Miner, with support of those activities provided by other members of the LRM sub-committee, Tony Phillips, John Carter and Andrew Leventhal.

\subsection{Case histories}

Case histories were an important facet of the seminar series and interactive website. The case-histories were published within Australian Geomechanics V46N2 June 2011 (AGS, 2011), as a stand-alone volume recording the use of AGS (2007) in landslide risk management throughout the nation. The case histories were subject to review for consistency by the members of the sub-committee. Selected case histories were presented within the seminars, usually being selected for relevance to the locale of the specific venue, and the case histories are linked to the interactive website. The case histories represent Australia-wide experience, and were published in Australian Geomechanics V46 N1 (AGS, 2011) - see Figure 6.

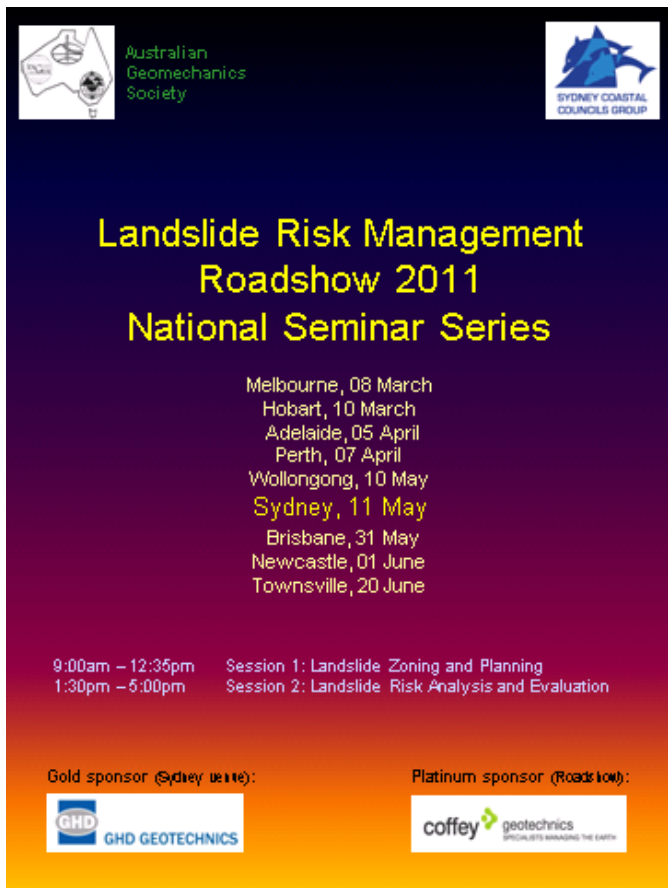

Figure 5 LRM Roadshow venues with sponsor identification

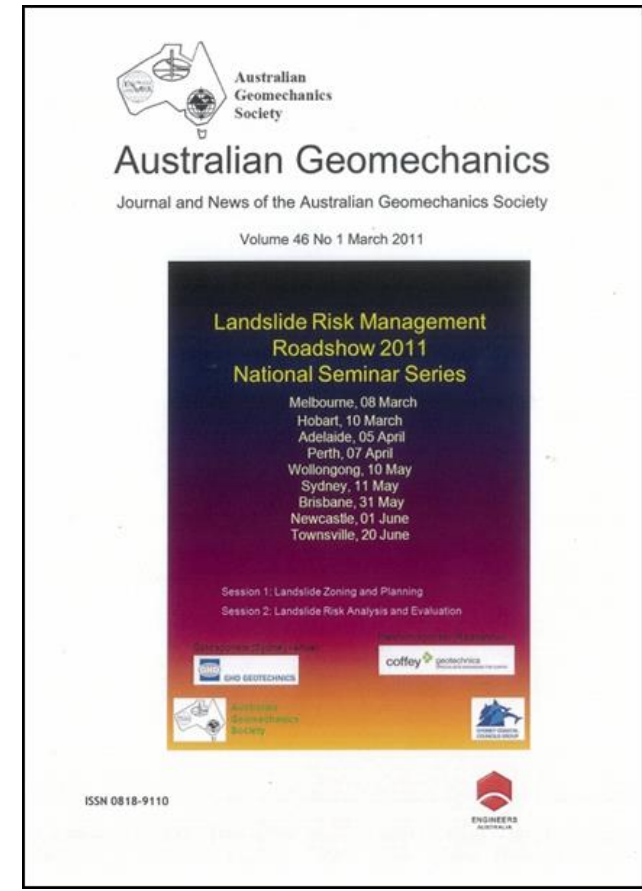

Figure 6 Cover of AG $\mathrm{V}_{4} 6 \mathrm{~N}_{1}$ which contained LRM case histories from around the nation 


\subsection{Education empowerment interactive website}

An interactive web-based site was developed to provide LRM education empowerment facilities, particularly based upon Australian experience (Leventhal et al., 2012). The website provides ready access to the facility for practitioners, regulators and the Australian public, as well as accommodating international interest.

Visitors to the site are introduced to LRM through a quiz based process with interactive links to education modules - see a screen-shot of the home page of the website in Figure 7. The outcomes from the 2011 National Roadshow seminars, including the final presentation material and a full copy of the presentations by the speakers, are available interactively. (The seminar that was recorded at Sydney is the basis of the presentation that can be viewed piece-by-piece from the interactive website).

The LRM EE website includes:

- Three web site access points: i) regulators, ii) practitioners, and iii) public.

- Top 10 education elements for each of the streams.

- Links to an entire LRM Risky Roadshow seminar presentation that includes bite-size elements of each of the face-to-face presentations throughout the day of the seminar (based upon the seminar presented in Sydney) with the full complement of PowerPoint slides.

The site is hosted and linked through the AGS website. This affords AGS the ability to update and modify the site as may be appropriate in the future.

The site has attracted over 200 visitors per month (August to December 2012), with visitors from 10 countries.

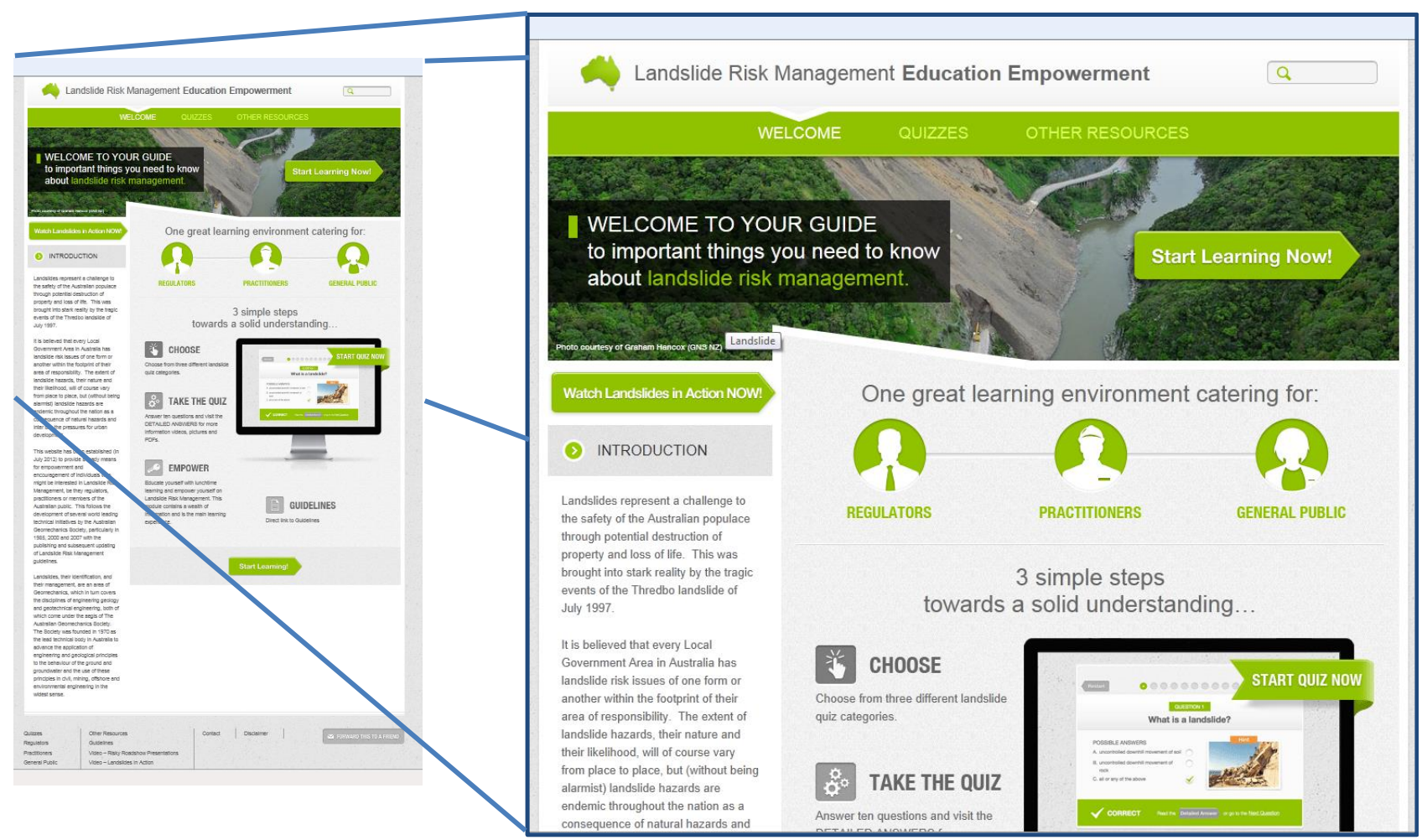

Figure 7 Screen shot of the LRM EE website, accessible through the AGS website www.australiangeomechanics.org 


\subsection{Other activities}

At State Government level, the Department of Community Safety (DCS) of the Queensland Government approached AGS to contribute to the review of their State Planning Policy addressing natural hazards (bushfire, flood and landslide). (It is noted that Queensland is currently the only state with a policy that addresses landslide management (QLD Govt, 2003)). The DCS was establishing a SPP 1/03 Review Landslide Advisory Group, and sought the involvement of AGS in this review. At the time of writing (April 2013), this activity is awaiting to be advanced by the Queensland State Government.

At the Local Government level, the authors are aware of the Local Government Areas and Regulators listed in Table 2 and Table 3 that have adopted LRM (with reference to AGS 2000 or AGS 2007) within natural hazard management policies. It is noted that the interest raised by the LRM Roadshow 2011 offers an opportunity for recognition of the LRM processes (as embedded within AGS (2007)) for incorporation within legislation throughout the nation. The intent of this would be to simplify procedures - through adoption of one protocol nation-wide, rather than a protocol per local government area. This is a potential opportunity for AGS to provide benefit to the broader Australian society, in line with the AGS constitution.

Table 2 Summary of NSW regulators' policies in relation to LRM and geotechnical issues as an example of the type of policies in place (as of 2011)

\begin{tabular}{|c|c|c|c|}
\hline Regulator & Policy Title & Date & Comment \\
\hline \multicolumn{4}{|c|}{ A: Landslide Risk Management } \\
\hline $\begin{array}{l}\text { NSW Department } \\
\text { Infrastructure, } \\
\text { Planning and } \\
\text { Natural Resources }\end{array}$ & $\begin{array}{l}\text { Kosciusko Alpine Resorts } \\
\text { Geotechnical Policy }\end{array}$ & Undated & $\begin{array}{l}\text { The first policy was based on AGS2000. First } \\
\text { published in about mid- } 2003 \text { and } \\
\text { after advice from/consultation with } \\
\text { GHD-Longmac. }\end{array}$ \\
\hline Pittwater Council & $\begin{array}{l}\text { Geotechnical Risk } \\
\text { Management Policy } 2009\end{array}$ & 2009 & $\begin{array}{l}\text { First adopted as an 'Interim Policy' in June } \\
2003 \text {, with amended versions since then. } \\
\text { Based on Kosciusko but with refinements. }\end{array}$ \\
\hline $\begin{array}{l}\text { Wollongong City } \\
\text { Council }\end{array}$ & $\begin{array}{l}\text { Wollongong City } \\
\text { Geotechnical Control Plan }\end{array}$ & 12 July 2006 & $\begin{array}{l}\text { Similar to Pittwater, but with 'local' } \\
\text { variations. Supersedes an earlier version from } \\
\text { 1990s or earlier as based on Warringah Shire } \\
\text { concept. }\end{array}$ \\
\hline $\begin{array}{l}\text { Gosford City } \\
\text { Council }\end{array}$ & $\begin{array}{l}\text { Gosford city Council } \\
\text { Development Control Plan } \\
\text { No } 163 \text { - 'Geotechnical } \\
\text { Requirements for } \\
\text { Development Applications' }\end{array}$ & $\begin{array}{l}29 \text { February } \\
2003\end{array}$ & Prescriptive for report content. \\
\hline $\begin{array}{l}\text { Warringah Shire } \\
\text { Council }\end{array}$ & $\begin{array}{l}\text { Draft Local Environment } \\
\text { Plan }\end{array}$ & 2009 & $\begin{array}{l}\text { Draft LEP includes a 'landslide risk map' } \\
\text { prepared by Coffey } 2006 \text { based on slope } \\
\text { angle, and a Geotechnical report addressing } \\
\text { LRM to AGS2000 is required for some zones. }\end{array}$ \\
\hline Manly Council & $\begin{array}{l}\text { Development Control Plan } \\
\text { for Landslip and } \\
\text { Subsidence } 2001\end{array}$ & $\begin{array}{l}\text { Issued 2001, } \\
\text { updated } \\
\text { March } 2003\end{array}$ & $\begin{array}{l}\text { Based on AGS2000 and zoning maps prepared } \\
\text { by Coffey Geosciences in 1999, using slope } \\
\text { angle predominantly. }\end{array}$ \\
\hline $\begin{array}{l}\text { Baulkham Hills } \\
\text { Shire Council }\end{array}$ & $\begin{array}{l}\text { Not sure if a formal policy } \\
\text { in general }\end{array}$ & & $\begin{array}{l}\text { There is a policy for getting an independent } \\
\text { peer review appointed by Council from a } \\
\text { panel of peer reviewers for areas of known } \\
\text { 'landslide hazard' usually being areas } \\
\text { identified by a development suitability zoning } \\
\text { study completed in late 1970s. }\end{array}$ \\
\hline
\end{tabular}




\begin{tabular}{|c|c|c|c|}
\hline Regulator & Policy Title & Date & Comment \\
\hline $\begin{array}{l}\text { Wingecarribee } \\
\text { Shire (Bowral } \\
\quad \text { area) }\end{array}$ & $\begin{array}{l}\text { DCP44 - Requirements for } \\
\text { the erection of buildings }\end{array}$ & $\begin{array}{c}\text { Draft 2006, } \\
\text { Final/adopted? }\end{array}$ & $\begin{array}{l}\text { Requires 'Geotechnical Risk Assessment' } \\
\text { report by suitably qualified consultant. Lists } \\
\text { information to be provided. } \\
\text { 'Risk' basis not defined. }\end{array}$ \\
\hline Ryde City Council & Not sure & & $\begin{array}{l}\text { Not sure how extensive but is based on } \\
\text { zoning maps prepared by Coffey. }\end{array}$ \\
\hline $\begin{array}{l}\text { Lake Macquarie } \\
\text { Shire Council }\end{array}$ & Not sure & & $\begin{array}{l}\text { Not sure how extensive but is based on } \\
\text { zoning maps prepared by Coffey. }\end{array}$ \\
\hline $\begin{array}{l}\text { RTA } \\
\text { (now Roads and } \\
\text { Marine Services) }\end{array}$ & $\begin{array}{l}\text { Guide to Slope } \\
\text { Risk Analysis } \\
\text { Version } 3.1\end{array}$ & NSW 2001 & $\begin{array}{l}\text { RTA system is based on AGS } 2000 \text { but tailored } \\
\text { to suit roads, using a qualitative assessment } \\
\text { scheme based on quantitative evaluation of } \\
\text { terminology. Primarily considers risk to life, } \\
\text { but risk to property also covered. }\end{array}$ \\
\hline RailCorp & $\begin{array}{l}\text { Geotechnical Risk } \\
\text { Assessment and Hazard } \\
\text { Management Guidelines } \\
\text { TMC401, Version } 1.1\end{array}$ & $\begin{array}{l}\text { Issued } \\
\text { December } \\
2009\end{array}$ & $\begin{array}{l}\text { Qualitative 'ranking' system, appears based } \\
\text { on AGS2000, but tailored to suit rail, and } \\
\text { primarily based on risk to life. }\end{array}$ \\
\hline \multicolumn{4}{|c|}{ B: Geotechnical Issues } \\
\hline $\begin{array}{l}\text { Woollahra } \\
\text { Municipal Council }\end{array}$ & $\begin{array}{l}\text { Guidelines for preparation } \\
\text { of Geotechnical and } \\
\text { Hydrogeological Reports }\end{array}$ & $\begin{array}{l}\text { Adopted } \\
9 \text { September } \\
2002\end{array}$ & $\begin{array}{l}\text { Aimed at issues associated with: } \\
\text { development in the alluvial areas with high } \\
\text { groundwater levels; temporary excavation } \\
\text { support; and effect of vibrations such as from } \\
\text { rock excavation. }\end{array}$ \\
\hline $\begin{array}{l}\text { Ku-ring-gai } \\
\text { Council }\end{array}$ & & About 2007 & Similar to Woollahra Council. \\
\hline $\begin{array}{l}\text { Mosman } \\
\text { Municipal Council }\end{array}$ & $\begin{array}{l}\text { Significant Rock Faces and } \\
\text { Retaining Walls Policy }\end{array}$ & 3 April 2007 & Limited as per title. \\
\hline $\begin{array}{l}\text { North Sydney } \\
\text { Council }\end{array}$ & Unsure whether formalised & & \\
\hline $\begin{array}{l}\text { Clarence River/ } \\
\text { Maclean Shire } \\
\text { Council }\end{array}$ & & & $\begin{array}{l}\text { Council has considered adopting policy } \\
\text { similar to Pittwater. }\end{array}$ \\
\hline
\end{tabular}


Table 3 State based LRM regulator policies

\begin{tabular}{|c|c|c|}
\hline State & Regulator & Scheme \\
\hline \multirow[t]{3}{*}{ Queensland } & $\begin{array}{l}\text { State Government through Department of Community } \\
\text { Safety }\end{array}$ & $\begin{array}{l}\text { Queensland remains the only state } \\
\text { in Australia with a state-wide policy } \\
\text { for LRM. }\end{array}$ \\
\hline & Gold Coast City Council, Townsville, Cairns & Constraints Codes and Overlays. \\
\hline & McKay, Ipswich, Sunshine Coast Regional Council & \\
\hline South Australia & Goyder Regional Council, Peterborough & $\begin{array}{l}\text { No formal planning instrument, } \\
\text { though identified under natural } \\
\text { hazards risk assessment. }\end{array}$ \\
\hline Tasmania & $\begin{array}{l}\text { West Tamar, City of Launceston, City of Hobart, Sullivans } \\
\text { Cove, Glenorchy, Kentish, Municipality of George Town }\end{array}$ & $\begin{array}{l}\text { Some provision within Planning } \\
\text { Schemes (but variable). }\end{array}$ \\
\hline Victoria & $\begin{array}{l}\text { Yarra Ranges, Colac Otway Shire, Mornington, Alpine } \\
\text { resorts, Baw Baw, Bass, Sth Gippsland, Murrindindi, } \\
\text { Bayside, Frankston, Cardinia, Moreland }\end{array}$ & Erosion Management Overlay. \\
\hline $\begin{array}{l}\text { Western } \\
\text { Australia }\end{array}$ & Stirling & $\begin{array}{l}\text { Reference made within planning } \\
\text { scheme. }\end{array}$ \\
\hline
\end{tabular}

\subsection{Applicability to slope instability in open cut mining and civil engineering}

There are a number of natural hazards that are relevant to urban, residential, rural and undeveloped property throughout Australia. These include flooding, bush fire, coastal processes, severe storms, flooding, landslides, earthquake and tsunami (Middlemann, 2007). The AGS (2007) suite of guidelines deals with landslide susceptibility, hazard and risk.

Slope instability occurs in many parts of urban and rural Australia (in every local government area across the nation, in one form or the other, in some area of responsibility) and often impacts on housing, roads, railways and other development, and the environment. This has been recognised by many local government councils and government authorities, and thus has led to the requirement by many local government councils for instability assessments prior to permitting building development.

The intent of the LRM guidelines, as expounded in AGS (2000), is:

- To establish uniform terminology.

- To define a general framework for landslide risk management.

- To provide guidance on methods which should be used to conduct the risk analysis.

- To provide information on acceptable and tolerable risks for loss-of-life.

In addition, the aim has been the application widely of LRM to slope engineering using risk assessment processes. This covers both civil engineering and mining situations.

With this pre-amble, it follows that the methodology and principles presented in AGS 2007 can be applied to both civil engineering and mining projects. LRM is one of the many tools available to the designer, constructor, authority and mine operator - for example, the NSW Roads and Traffic Authority (RTA) as it was, Roads and Maritime Services (RMS) as it is now, recognises the risk management approach for their inventory of cuttings and fills, of which there are many thousands throughout the state.

The LRM methodology enables a rationale to be documented for engineering assessment of uncertainties, but with the practitioner's best estimate at that time. By documenting the rationale and factual basis, a defensible assessment is provided which can be readily updated as more data comes to hand. This is implicit in the 'feedback loop' shown on the right hand side of Figure 2. This approach has been recognised 
as an issue in mine slope engineering (e.g. as presented by Barry McMahon in the E.H. Davis lecture of 1985 (McMahon, 1985)), not least-wise as a consequence of uncertainty.

Although AGS 2007 is written in the context of 'landslides' which are usually thought of as naturally occurring events, the definition of landslide in AGS 2007 (AGS 2007c Appendix B; 'the term landslide denotes 'the movement of a mass of rock, debris or earth down a slope") is sufficiently general that slopes constructed or formed during civil engineering works (or similar) or by mining, can and should, be included. This would also include temporary works cases. Completion of deterministic analyses (such as Factor of Safety by limit equilibrium analysis) can be used to form part of the methodology for the assessment. Use of sensitivity analyses can assist with evaluation of the likelihood of the event (failure scenario) being considered. Use can also be made of software designed to derive a probability of failure, for example as discussed by Hurley et al. (2012).

Consideration would have to be given to use of appropriate risk criteria for the cases being considered. There is a rational argument for adoption of Tolerable Risk Criteria for mine pit slopes given the management usually associated with such mining, and perhaps for temporary works provided monitoring and reaction plans are included. With appropriate risk management procedures, substantially higher risks may also be justified and accepted by all parties involved. The important aspect here is that the risk assessment, including assumptions and limitations, and risk management requirements are properly documented, discussed and understood and accepted by all parties associated with the assessment process. In the mining context, consequences can include loss of production (such as management of the large scale failures of the Chuquicamata mine east slope of February 1969 and the Bingham Canyon pit slope of April 2013), and business reputation. These two examples appear to have recognised such consequences and hence demonstrate the value of hazard identification, monitoring and implementation of action plans with trigger levels under a risk management program. It is also a reasonable expectation that there are likely to be more funds available for a focused landslide risk appraisal in the mining context.

Though the authors consider that such a process as the one advocated provides a defensible case, should the assessment be found to be incorrect there will inevitability be subsequent scrutiny of a 'failure event'. Practitioners must be cognisant of the test for negligence (what a similarly skilled practitioner at the same time and same place would have reasonably done and/or concluded) and should document the uncertainties identified and the assumptions made (and/or tested).

All parties need input, though frequently in a civil engineering sense the regulator is 'the last-man-standing' in the context of risk transfer, and therefore often will provide the acceptable risk limits applicable to the community it represents - be it home owners, occupants, road users, or the general public. In the mining context, the mine manager is where the 'buck stops', though mine regulators may be involved in the approval process.

It should also be noted that risk avoidance is a valid risk management option.

\section{Conclusions}

A framework for LRM for the nation exists, and tools and training means are available to practitioners. Additionally, guidance is available for regulators for implementation of LRM policies and guidance is also available to the general public. The methodology and principles of LRM can be used for both civil engineering and mining projects provided the rationale is properly documented, understood and accepted by all parties involved.

The success of the 2011 nation-wide LRM Roadshow highlighted the interest and relevance to the general community, regulators and practitioners alike. Significant gains have been made, but on-going work and development, including increased public awareness, recognition by other engineering disciplines of the benefits of cross fertilisation, on-going training and education, together with consistent planning policy across the nation, is still needed. 
The national committee of the AGS has determined that the objective of the LRM sub-committee, in delivering a functional LRM framework to the nation, has been achieved, and accordingly this paper is likely to be the final technical update under the current aegis from the national committee.

\section{References}

AGS (2000) Landslide risk management concepts and guidelines, Australian Geomechanics, Australian Geomechanics Society, Vol. 35, No. 1, March 2000, reprinted in Vol. 37, No. 2, May 2002.

AGS (2002) Risky Roadshow, Australian Geomechanics, Australian Geomechanics Society, Vol. 37, No. 2, May 2002.

AGS (2006) National Professional Engineers Register (NPER) - Guideline for applicants on Eligibility Criteria and Procedures for recognition in the Specific Area of Practice of Landslide Risk Management, Australian Geomechanics, Australian Geomechanics Society, Vol. 41, No. 2, June.

AGS (2007) - a collective identification for the suite of papers AGS (2007a) to AGS (2007e).

AGS (2007a) Guideline for landslide susceptibility, hazard and risk zoning for land use planning, Australian Geomechanics, Australian Geomechanics Society, Vol. 42, No. 1, March 2007.

AGS (2007b) Commentary on guideline for landslide susceptibility, hazard and risk zoning for land use planning, Australian Geomechanics, Australian Geomechanics Society, Vol. 42, No. 1, March 2007.

AGS (2007c) Practice note guidelines for landslide risk management, Australian Geomechanics, Australian Geomechanics Society, Vol. 42, No. 1, March 2007.

AGS (2007d) Commentary on practice note guidelines for landslide risk management, Australian Geomechanics, Australian Geomechanics Society, Vol. 42, No. 1, March 2007.

AGS (2007e) Australian GeoGuides for Slope Management and Maintenance, Australian Geomechanics, Australian Geomechanics Society, Vol. 42, No. 1, March 2007.

AGS (2011) LRM Case histories Issue, Australian Geomechanics, Australian Geomechanics Society, Vol. 46, No. 2, March 2011.

Fell, R., Corominas, J., Bonnard, C., Cascini, L., Leroi, E. and Savage, W.Z. (2008a) Engineering Geology, Guidelines for landslide susceptibility, hazard and risk zoning for land use planning, Vol. 102, prepared on behalf of JTC-1 Joint Technical Committee on Landslides and Engineered Slopes.

Fell, R., Corominas, J., Bonnard, C., Cascini, L., Leroi, E. and Savage, W.Z. (2008b) Engineering Geology, Commentary: Guidelines for landslide susceptibility, hazard and risk zoning for land use planning, Vol. 102, prepared on behalf of JTC-1 Joint Technical Committee on Landslides and Engineered Slopes.

Hurley, G., Pollock, D. and Haberfield, C. (2012) Case Study: Using Limit equilibrium analysis in landslide risk assessments, in Proceedings 11th Australia - New Zealand Conference on Geomechanics, Ground engineering in a changing world, 15-18 July 2012, Melbourne, Australia.

Leventhal, A.R. and Walker, B.F. (2005a) Risky Business - development and implementation of a national landslide risk management system, in Proceedings International Conference on Landslide Risk Management, O. Hungr, R. Couture, E. Eberhardt and R. Fell (eds), 31 May-3 June, 2005, Vancouver, Canada, Taylor \& Francis.

Leventhal, A.R. and Walker, B.F. (2005b) Risky Business: The development and implementation of a national landslide risk management system for Australia - the state-of-play, September 2005, Australian Geomechanics, Vol. 40, No. 4, December 2005.

Leventhal, A., Walker, B., Miner, A., Phillips, A. and Carter, J. (2012) Landslide risk management in Australia 2012, in Proceedings 11th Australia - New Zealand Conference on Geomechanics, Ground engineering in a changing world, 15-18 July 2012, Melbourne, Australia.

McMahon, B.K. (1985) Geotechnical design in the face of uncertainty, E.H. Davis Memorial Award, Australian Geomechanics News, Australian Geomechanics Society, No. 10, December 1985.

Middlemann, M.H. (2007) Natural hazards in Australia - identifying risk analysis requirements, Geoscience Australia.

QLD Govt (2003) Queensland Government, Mitigating the adverse impacts of flood, bushfire and landslide, Department of Local Government and Planning, Department of Emergency Services, State Government Planning Policy 1/03 Guideline, June 2003.

Walker, B.F., Dale, M., Fell, R., Jeffery, R., Leventhal, A., McMahon, M., Mostyn, G. and Phillips, A. (1985) Geotechnical risk associated with hillside development, Australian Geomechanics News, acting as a sub-committee of the Australian Geomechanics Society, No. 10, pp. 2935. 
